\title{
CrimRxiv
}

\section{Review 2 of "Everyday}

Aesthetics, Space, and the

Sensory: Fear of Crime and

Affect in Inner Sydney"

Nigel South

Published on: May 10, 2021

License: Creative Commons Attribution 4.0 International License (CC-BY 4.0). 
Vote: Publish as is

[For votes to count, referees must reasonably explain why they voted as they did. Thus, please explain your vote. If you voted to publish pending minor changes, specify each change, why it is needed, and, possibly, how it should/could be done.]

The authors position the paper in the relevant literature while opening space for critique, synthesis and development; interesting, nice quotes, well written.

Persuasive about reasons for applying a sensory (etc) awareness to the data analysis Authors might be interested in exploring further the connections between fear and darkness, night and nature, the gothic - how the safe and familiar is turned into the unknown and uncanny etc etc - see e.g South 'Monstrous Nature' in M Brown and E Carrabine (eds) Routledge Handbook of visual Criminology and references therein.

Some themes in the paper might connect to ideas about noise vs silence in the city and also 'rights' in relation to the city see eg García Ruiz and South (2019) in CMC https://journals.sagepub.com/doi/pdf/10.1177/1741659017751223 And - Brisman, García Ruiz, McClanahan and South (2021) 'Exploring sound and noise in the urban environment: Tensions between cultural expression and municipal control, health and inequality, police power and resistance' in Persak and DiRonco (eds) Harm and Disorder in the Urban Space Routledge.

Needs an edit check for missing words etc; is there an alternative to 'master' narratives? (especially in relation to feminist concerns) eg primary narratives?

Main omission seems to be little acknowledgement of the diverse forms and products of media that feed imagined threats etc. 